\title{
Reliability of spring recession curve analysis as a function of the temporal resolution of the monitoring dataset
}

\author{
Elena Cerino Abdin ${ }^{1} \cdot$ Glenda Taddia $^{1} \cdot$ Martina Gizzi $^{1}$ (1) - Stefano Lo Russo ${ }^{1}$
}

Received: 9 March 2020 / Accepted: 4 March 2021 / Published online: 19 March 2021

(c) The Author(s) 2021

\begin{abstract}
Mountain springs represent one of the largest and most precious sources of potable water in Italy, necessary to meet the water needs of the population. Optimizing the present and future management strategies of mountain groundwater resources has become increasingly necessary. The accuracy and frequency of the flow rate $(Q)$ measurements determine and restrict the processes that can be studied using spring hydrograph and recession curve analysis. Therefore, to properly define mountain aquifers' hydrogeological properties, it turns out important to highlight the variation of the error in the estimation of the hydrogeological parameters as the time interval of sampling varies. In this paper, recession curve analysis was performed on two different mountain springs (Spring 1 and Spring 2) of north-western Italy, firstly considering available 4-h resolution measuring data and subsequently by resampling data to simulate longer sampling intervals of $1,3,7,15$, and 30 days. The resulting distribution of errors introduced by longer acquisition intervals underlined how the percentage error increases with increasing acquisition interval. For obtaining an adequate estimation of mountain aquifer hydrodynamic parameters, in place of continuous hourly data, 1-day and 3-day sampling intervals with associated errors respectively lower than 5\% and $10 \%$ were found to be valid.
\end{abstract}

Keywords Spring hydrograph $\cdot$ Recession curve $\cdot$ Mountain spring $\cdot$ Groundwater management $\cdot$ Groundwater monitoring

\section{Introduction}

Global water demand has been increasing worldwide by about $1 \%$ per year since the 1980 s, driven by a combination of population growth, socio-economic development, changing consumption patterns and it will continue to grow significantly over the foreseeable future. At the same time, the global water cycle has intensified due to climate change, urbanisation, deforestation and increasingly intensive agricultural practices (Unesco 2019).

In Italy, $84.3 \%$ of the nation's clean water derives from groundwater, including $48.0 \%$ from wells and $36.3 \%$ from springs, while $15.6 \%$ is derived from surface waters and the remaining $0.1 \%$ from marine water. Springs, therefore, represent one of the country's largest and most precious sources

Martina Gizzi

martina.gizzi@polito.it

1 Department of Environment, Land and Infrastructure Engineering (DIATI), Politecnico di Torino, C.so Duca degli Abruzzi 24, 10129 Torino, Italy of water, necessary to meet the water needs of the population (Istat 2018).

During recent decades, different hydrological issues, including the gradual drying up of many springs, low discharge rates during dry months and formerly perennial springs that have become seasonal, have been reported by authors across the Italian Alps and mountain Apennines areas. These trends have been found to be linked both to the overexploitation of groundwater resources and to climate change (Cambi and Dragoni 2000; Fiorillo et al. 2007; Gattinoni and Francani 2010).

Protecting and optimizing the present and future management of mountain groundwater resources, understanding their recharging system from both geological and hydrogeological perspectives, has become increasingly necessary for formulating adequate resource management strategies (Lo Russo et al. 2015).

A large number of methodologies have been developed over decades to derive hydrogeological information about mountain springs' recharging systems. In the early 1900s, Boussinesq $(1877,1904)$, and Maillet (1905) developed analytical models to quantitatively investigate spring recession 
mechanisms and estimate the hydrological properties of aquifers, establishing different mathematical relationships between spring discharge rates $(Q)$ and time $(t)$. Such methods were used over time to determine the potential of storage and exploitation of underground water resources (Nathan and McMahon 1990; Sugiyama 1996; Shevenell 1996; Dewandel et al. 2010).

Besides, autocorrelation and cross-correlation methods were recently elaborated and applied to spring monitoring datasets by different authors: in their works, Desmarais and Rojstaczer 2001; Fiorillo and Doglioni 2010; Galleani et al. 2011, Lo Russo et al. 2014, Banzato et al. 2017 showed how drainage models and springs' vulnerability can be evaluated by analysing datasets of discharge $(Q)$, precipitation $(P)$, temperature $(T)$ and electrical conductivity (EC). However, such statistical methods require to be applied strictly to continuous and multi-year recorded time series of data of $\mathrm{P}, \mathrm{Q}, \mathrm{T}$ and $\mathrm{EC}$ parameters. This aspect currently represents a key limiting factor for many practical hydrogeological spring investigations with short execution times (Kresic and Bonacci 2010).

As also reported by Tobin and Schwartz (2016), in remote alpine areas, continuous monitoring and data collection of springs' hydrogeological parameters are often hampered by technical and logistical problems.

For these reasons, hydrograph analysis is still one of the most common and effective ways to assess the properties of a spring aquifer, such as the type and quantity of groundwater reserves (Dewandel et al. 2010; Fiorillo et al. 2012; Vashisht and Bam 2013; Cervi et al. 2014; Giacopetti et al. 2016; Jakada et al. 2019).

Nevertheless, a correct estimate of the hydrogeological parameters of the aquifer cannot be separated from the use of discharge $(Q)$ values, recorded with high frequency and accuracy.

In particular, as the constancy in flow rate $(Q)$ measurements determines and restrict the processes that can be studied through recession curve methods, it turns out to be important to know the error's extent in the quantitative estimation of the hydrogeological parameters as the time interval of sampling varies.

Over time, the topic related to the analysis of appropriate time intervals for the analysis of the aquifer recession mechanisms has been discussed in the literature (Rupp and Selker 2006; Roques et al. 2017). In these studies, the attention turned out to be mainly focused on the type and quality of the results that can be obtained by applying available simplified analytical solutions to recession curves. Differently, the main aim of this study is to identify the minimum time interval in the recording of the spring discharge parameter that can be considered valid for a correct estimation of aquifer groundwater reserves. This information could be usefully considered by geologists in the planning of sampling campaigns in mountain environments, such as the one described, places where it is still frequently not possible to install probes for the continuous recording of spring hydrogeological parameters.

In this paper, complete recession curve analysis using Boussinesq's $(1877,1904)$ and Maillet's (1905) analytical solutions were conducted on two different porous springs (Spring 1 and Spring 2), located in the Italian Western Alps.

Recession curve analysis were firstly performed using the 4 hourly Q-measurement data with annual duration, available for both the selected case studies. Subsequently, the same analysis was carried out on different datasets with sampling intervals of $1,3,7,15$ and 30 days, generated from the original 4 hourly Q-measurement data.

The error in estimating the hydrogeological parameters of the groundwater volume stored in the system at the beginning and the end of the recession process $\left(W_{o}, W_{d}\right)$ and the coefficient of discharge $(\alpha)$ were statistically analysed to understand which acquisition interval can be considered adequate to perform acceptable quantitative estimates of aquifer's parameters.

\section{Methods}

\section{Case studies}

Water reserves in mountainous areas are essentially located in extensive and thick sedimentary non-cohesive bodies (debris, landslide and glacial deposits) and/or in large volumes of intensely fractured and loosened rocks, involved in deep-seated gravitational slope deformation (DSGSD) areas (Banzato et al. 2015; Ostermann et al. 2016; De Luca et al. 2019).

The selected case studies are represented by two different mountain springs (Spring 1 and Spring 2), located in the alpine region of north-western Italy. From a geological point of view, Spring 1 and 2 are supplied by porous aquifers set in debris deposits, placed over impermeable metamorphic rocks (Figs. 1 and 2). The undeformed bedrock is characterized by lithological complexes of the tectonostratigraphic successions of the Italian Austoalpine Domain (Polino et al. 2002). The overlying debris deposits consist of sediments composed of fractured heterometric block, with dimensions from centimetrical to plurimetrical with chaotic disposition, mixed with variable quantities of a fine silty-sandy matrix. These deposits are associated to accumulations with very variable shapes and sizes, depending on the local morphology of the slope.

Due to the high permeability values, the described deposits turn to be very favourable to the storage of large quantities of water. The water infiltrated in the subsoil is forced to slow down its flow at the interface between the heavily 


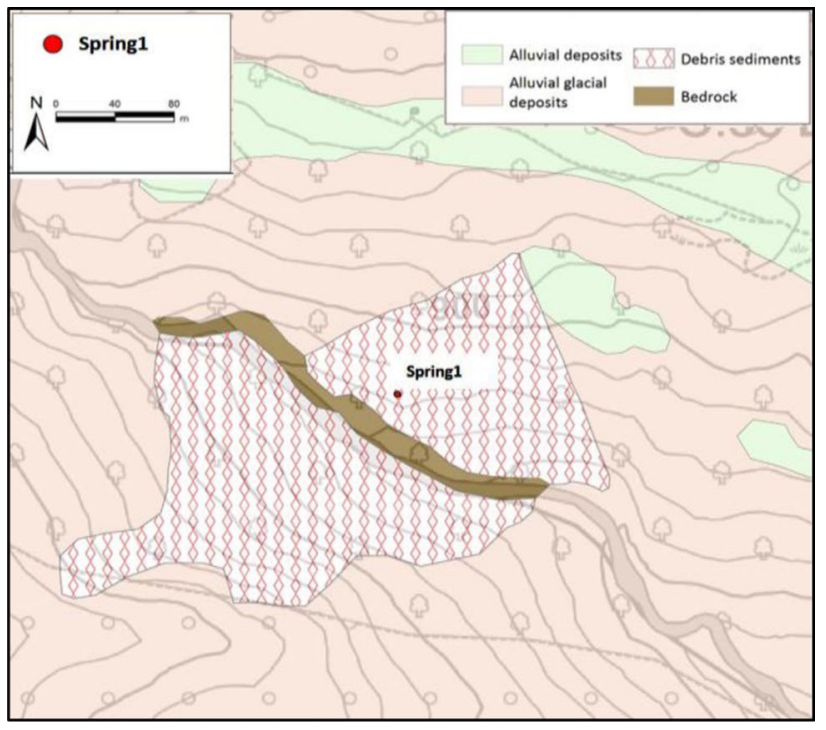

Fig. 1 Location and schematic geological map for Spring 1

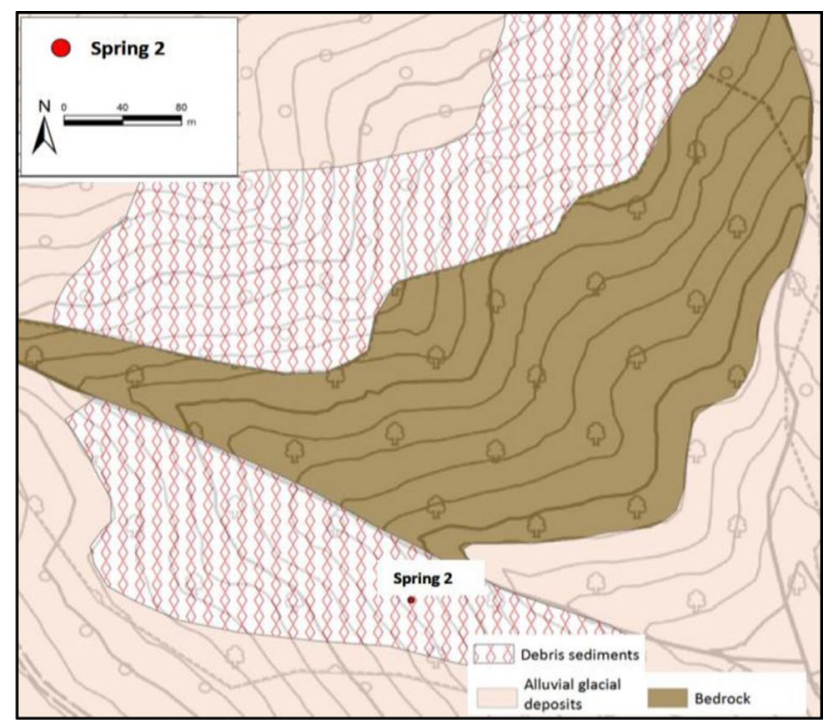

Fig. 2 Location and schematic geological map for Spring 2

porous debris deposits until the impermeable bedrock. The appearance of springs is probably correlated to this permeability limit.

Spring 1 and Spring 2 were selected as, although they are mountain sources for which it is often difficult to find data, by means of their available hourly dataset was possible to make different evaluations by modifying the sampling intervals. Moreover, despite their similar geological structure, discharge values (1/s) of Spring 1 and Spring 2, recorded continuously by monitoring systems with an acquisition interval of four hours during 2017, show very different variation trends (Figs. 3 and 4).
According to the estimated Variability Index Iv (Meinzer 1927) of 0.98, the discharge rate of Spring 1 can be considered sub-variable. The maximum recorded discharge rate is $7.8 \mathrm{l} / \mathrm{s}$, while the minimum discharge rate value turns to be $2.7 \mathrm{l} / \mathrm{s}$.

The discharge rate of Spring 2 is variable (Variability Index of 2.30), with a maximum recorded discharge rate that exceeds $30 \mathrm{l} / \mathrm{s}$ and a minimum discharge rate of $1.6 \mathrm{l} / \mathrm{s}$.

Based on the available monitoring data (Fig. 3 and 4), both Spring 1 Spring 2 do not appear to have a rapid response to meteoric events or a direct correlation with rainy events.

\section{Hydrograph analysis}

The final graphical result of the various processes that govern the transformation of precipitation and other water inputs in the drainage area into the single output at the spring is called the spring hydrograph (Figs. 3 and 4).

Schematically, spring hydrographs are defined by a rising limb (AP), a flood peak (P) and a falling limb or recession curve (PC) (Fig. 5). The rising limb characterises the first part of a hydrograph, where an increase in discharge $(Q)$ is recorded and very different responses can occur in relation to countless hydrogeological factors.

On the opposite, the falling limb or recession curve is characterized by a gradual decrease in discharge. It extends from the discharge peak to the base of the next rising limb and corresponds to a period with no significant precipitation.

By analysing the recession curve, it is generally possible to identify an initial section where the decrease rate is more marked called decrease curve, followed by a more slowly decreasing flow, called depletion curve.

The decrease curve corresponds specifically to the decrease in spring discharge that results from the persistence of the short circuit infiltration phenomenon, during which the unsaturated zone of the aquifer is still unaffected.

The gradual decrease in discharge in the depletion curve is instead related to the emptying of the saturated zone of the system in an unaffected regime. Some authors used to utilize the term infiltration or quick-flow curve to identify the decrease curve, while the depletion curve was sometimes called slow flow, exhaustion or the base flow curve (Civita 2008).

The analysis of spring discharge hydrographs is still nowadays one of the most suitable tools for the study of mountain springs and the definition of aquifer characteristics, such as the type and quantity of its groundwater reserves.

Over the decades, many authors have worked on recession curve modelling, establishing different mathematical relationships between spring discharge $(Q)$ and time $(t)$ that allowed to estimate the hydrological significance of the 


\section{SPRING 1}

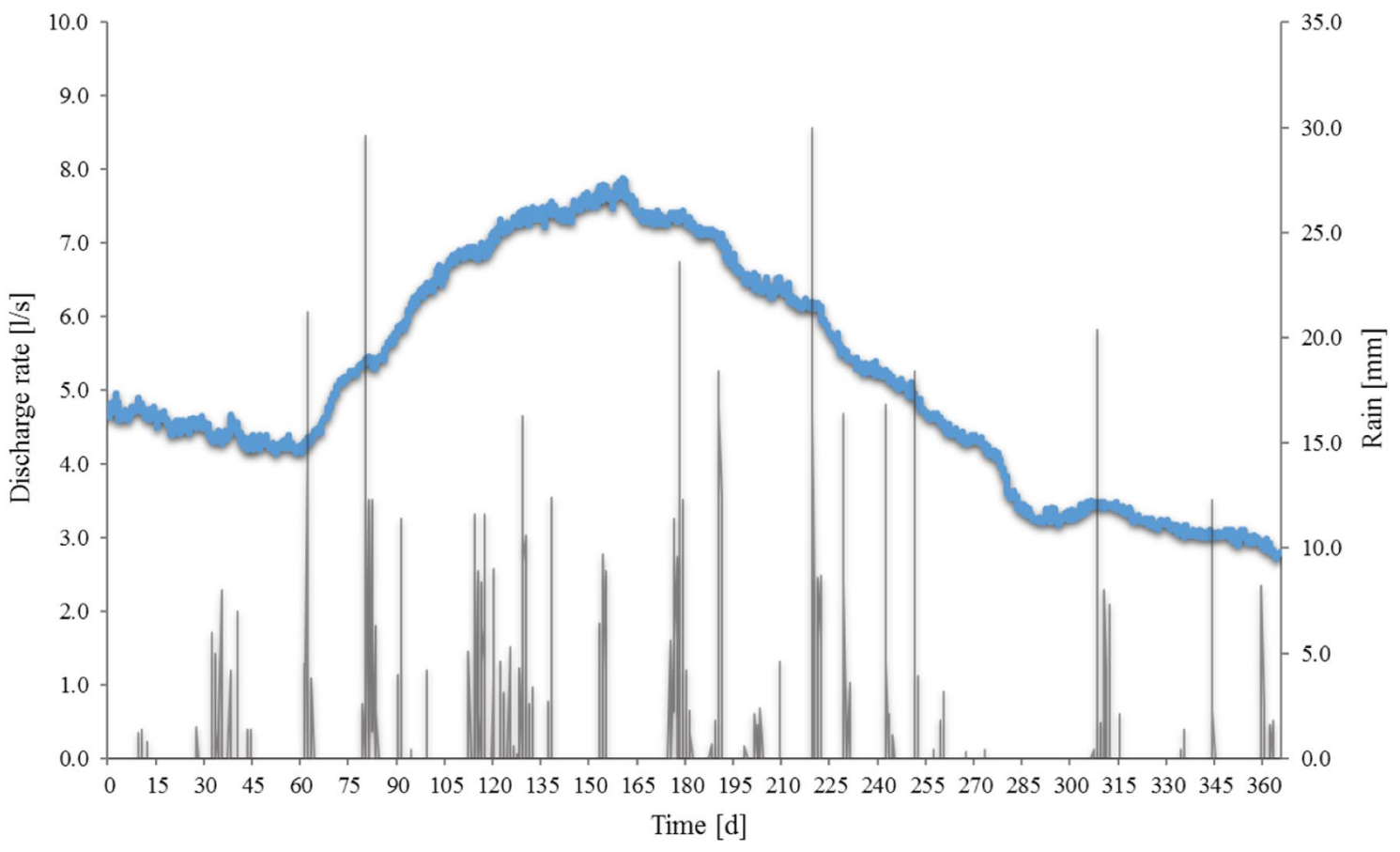

Fig. 3 Monitoring data for the Spring 1-test site (2017). Comparison between discharge rate trend (in blue) and rain trend (in grey). Automatic acquisition interval of $4 \mathrm{~h}$

Fig. 4 Monitoring data for the Spring 2-test site (2017). Comparison between discharge rate trend (in blue) and rain trend (in grey). Automatic acquisition interval of $4 \mathrm{~h}$

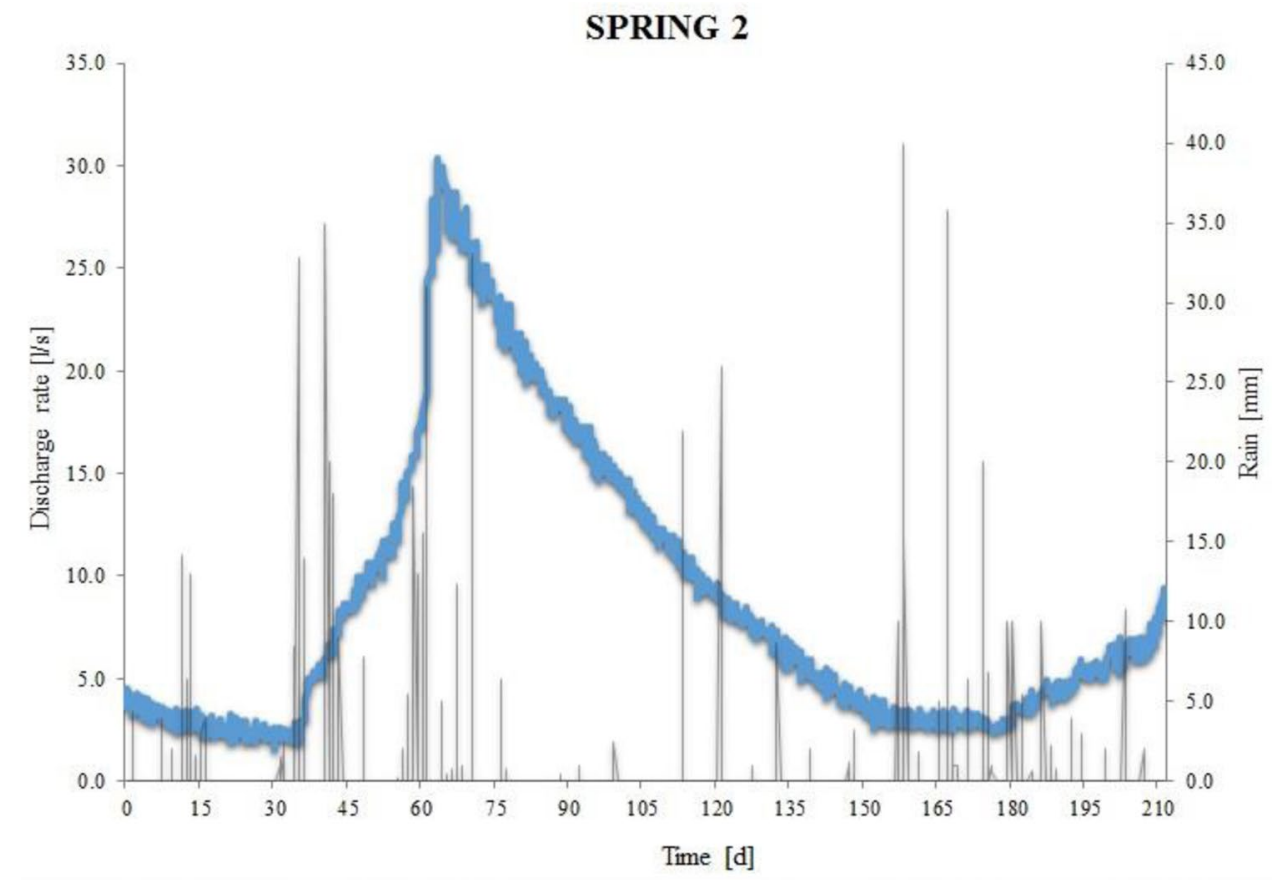

discharge function parameters and the hydrological properties of aquifers (Amit et al. 2002).

Boussinesq (1904) and Maillet (1905) proposed two analytical formulas that described the dependence of the flow rate at a specified time $\left(\mathrm{Q}_{t}\right)$ on the flow at the beginning of the recession $\left(\mathrm{Q}_{0}\right)$, making it possible to correctly calculate the volume of water discharged over time (Kresic 2007). 


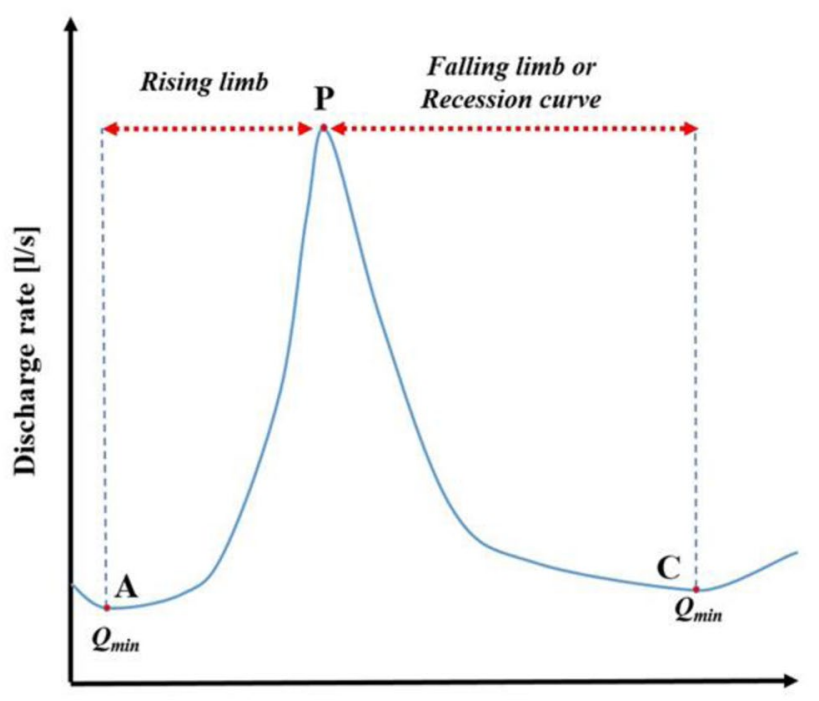

Time [d]

Fig.5 Schematic trend of a spring hydrograph

In detail, Boussinesq (1904) developed an exact analytical solution of the diffusion equation that describes flow through a porous medium, by considering the simplifying assumptions of a porous, free, homogeneous and isotropic aquifer, with the aquifer being limited by an impermeable horizontal layer at the level of the outlet (Eq. 1):

$Q_{t}=\frac{Q_{0}}{\left(\left(1+\alpha\left(t-t_{0}\right)\right)^{2}\right.}$

where $t[d]$ is the time since the beginning of recession for which the flow rate is calculated; $t_{0}[d]$ is the time at the beginning of recession usually (but not necessarily) set equal to $0, Q_{t}\left[\mathrm{~m}^{3} \mathrm{~s}^{-1}\right]$ is the flow rate value at $t \neq t_{0} ; Q_{0}\left[\mathrm{~m}^{3} \mathrm{~s}^{-1}\right]$ is the flow rate at the beginning of recession $t=t_{0} ; \alpha\left[d^{-1}\right]$ is a constant, called recession coefficient, depending on the aquifer hydraulic systems as aquifer transmissivity, storage coefficient and the catchment area (Eq. 2).

$\alpha=\frac{\sqrt{Q_{0}}-\sqrt{Q_{t}}}{\sqrt{Q_{t}} t}$
Maillet (1905) showed instead that the recession of a spring can be represented by an exponential formula, implying a linear relationship between the hydraulic head and flow rate (Eq. 3):

$Q_{t}=Q_{0} e^{-\alpha\left(t-t_{0}\right)}$

where the recession coefficient $(\alpha)$ can be determined through the following equation (Eq. 4).

$\alpha=\frac{\log \mathrm{Q}_{0}-\log \mathrm{Q}_{\mathrm{t}}}{e\left(t-\mathrm{t}_{0}\right)}$

Both in Boussinesq (1904) and Maillet (1905), the recession coefficient equations were used to determine important hydrogeological parameters: $W_{0}$, the groundwater volume stored above the spring level at the end of the recharging season (beginning of the recession) and $W_{d}$, the groundwater volume stored at the end recession period (Table 1).

The analysis of mathematical models elaborated by Boussinesq (1904) and Maillet (1905), leads to understanding how correct estimates of the aquifers hydrogeological parameters cannot be obtained without using discharge $(Q)$ values recorded with a certain frequency and accuracy.

However, for springs located in mountain environments, such as analysed springs, it is often not possible to perform the continuous recording of the hydrogeological parameters.

For this reason, in this work, a double calculation approach has been applied on both analysed spring (Spring 1 and Spring 2). Hydrogeological parameters $\left(\alpha, W_{0}\right.$ and $W_{d}$ ) computations, by means of Boussinesq (1904) and Maillet (1905) methods, were firstly performed considering the original $4 \mathrm{~h}$ sampling resolution of the recorded dataset (Figs. 3 and 4). Subsequently, the two series with 4-h sampling resolution were resampled to simulate acquisition intervals equal to 1, 3, 7, 15 and 30 days (see Fig. 6). For each acquisition interval, a different number of datasets were created starting from the original series and by moving forward time, to obtain all the possible datasets of a fixed sampling interval. In total, the resampling produced 168 30-day sampling datasets, 84 15-day sampling datasets, 427 -day sampling datasets, 18 3-day sampling datasets and 61 -day

Table 1 Boussinesq (1904) and Maillet (1905) equations to determine the groundwater volume stored at the beginning of recession period $\left(W_{0}\right)$ and the groundwater volume stored at the end of the recession period $\left(W_{d}\right)$

Boussinesq (1904)

Maillet (1905)

$$
\begin{aligned}
& W_{0}=\frac{Q_{0}}{\alpha(1+\alpha t)^{2}} \times 86400(5) \\
& W_{d}=\left[\frac{Q_{0}}{\alpha}-\frac{Q_{0}}{\alpha(1+\alpha t)}\right] \times 86400
\end{aligned}
$$

$$
\begin{aligned}
& W_{0}=\frac{Q_{0}}{\alpha} \times 86400(7) \\
& W_{d}=\frac{\left(Q_{0}-Q_{t}\right)}{\alpha} \times 86400(8)
\end{aligned}
$$

Where:

$Q_{t}\left[\mathrm{~m}^{3} \mathrm{~s}^{-1}\right]$ is the flow rate value at $t \neq t_{0}$;

$Q_{0}\left[\mathrm{~m}^{3} \mathrm{~s}^{-1}\right]$ is the flow rate at $t=t_{0}$;

$\alpha\left[d^{-1}\right]$ is the recession coefficient 

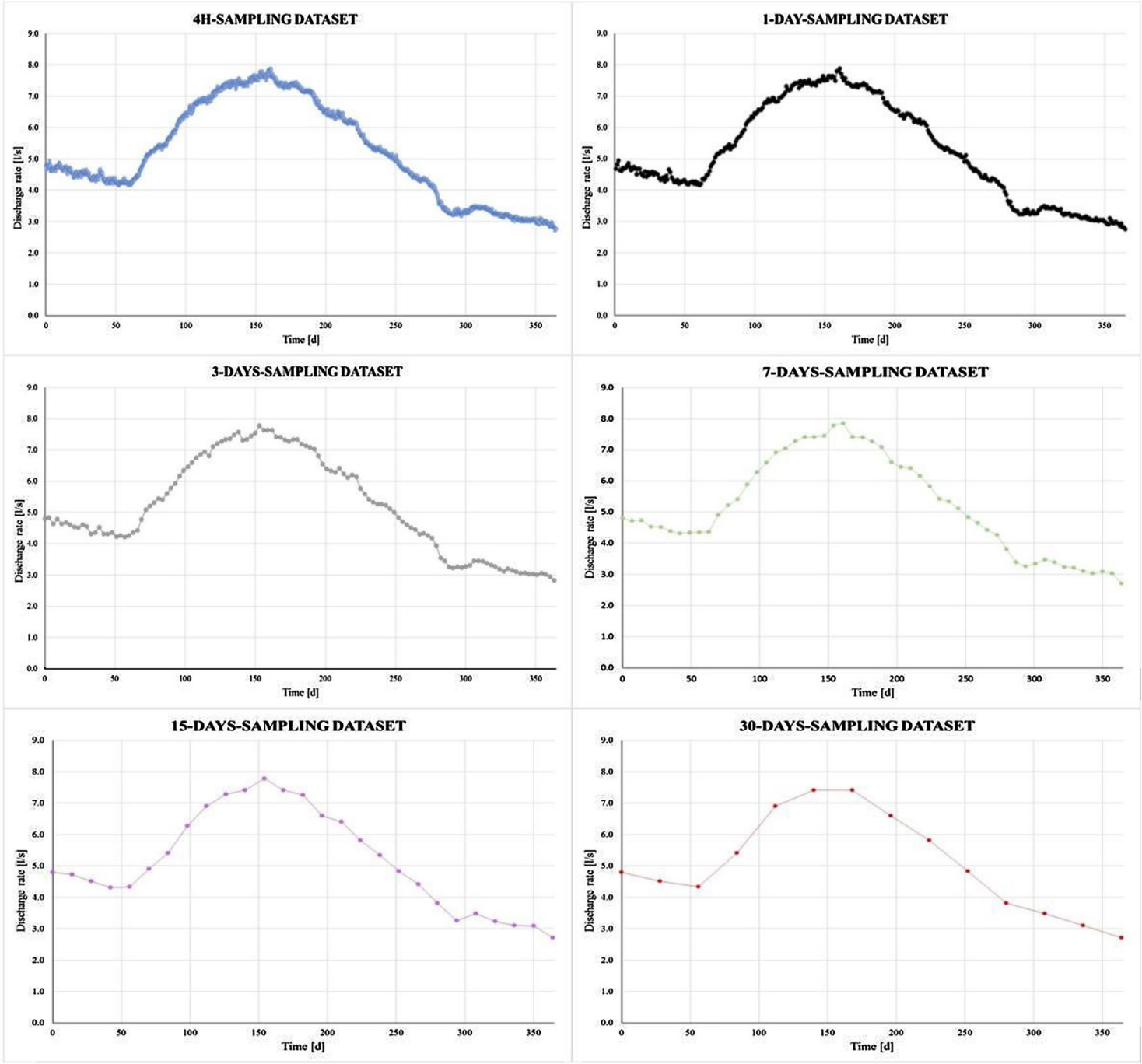

Fig. 6 Examples of the different Spring 1-hydrographs, obtained using monitoring datasets with sampling intervals respectively equal to 4 h (in blue) 1 day (in black), 3 days (in grey), 7 days (in green), 15 days (in violet) and 30 days (in red)

sampling datasets. A comparison of these different datasets is represented in Fig. 6.

The validity of the tested analytical methods for estimating aquifer hydrogeological parameters $\left(\alpha, W_{o}, W_{d}\right)$ also in case studies characterised by non-continuous monitoring was then evaluated by comparing the values obtained using the 4-h dataset with the ones obtained using the $1,3,7,15,30$ days sampling resolution datasets.

Distributions of estimated percentage errors, calculated with respect to the original dataset $(4 \mathrm{~h})$, were then plotted with the aim to identify the minimum acquisition time interval that can be considered adequate to formulate acceptable estimates of aquifer reserves.

\section{Results}

\section{Recession analysis-original dataset}

For each case study (Spring 1 and Spring 2), complete recession curves (i.e., no missing data) were generated using $Q$-values recorded with an acquisition interval of 4 hours (Figs. 6 and 7).

The results of the recession analysis, obtained by applying Boussinesq (1904) and Maillet (1905) methods on the 4-h sampling resolution dataset, are reported in Table 2.

By comparing the results obtained for Spring 1 by the two methods, the $W_{0}$ values turn out to be fairly divergent $\left(196,304 \mathrm{~m}^{3}\right.$ Boussinesq method and 129,696 $\mathrm{m}^{3}$ Maillet method), while the two methods provided similar values for 


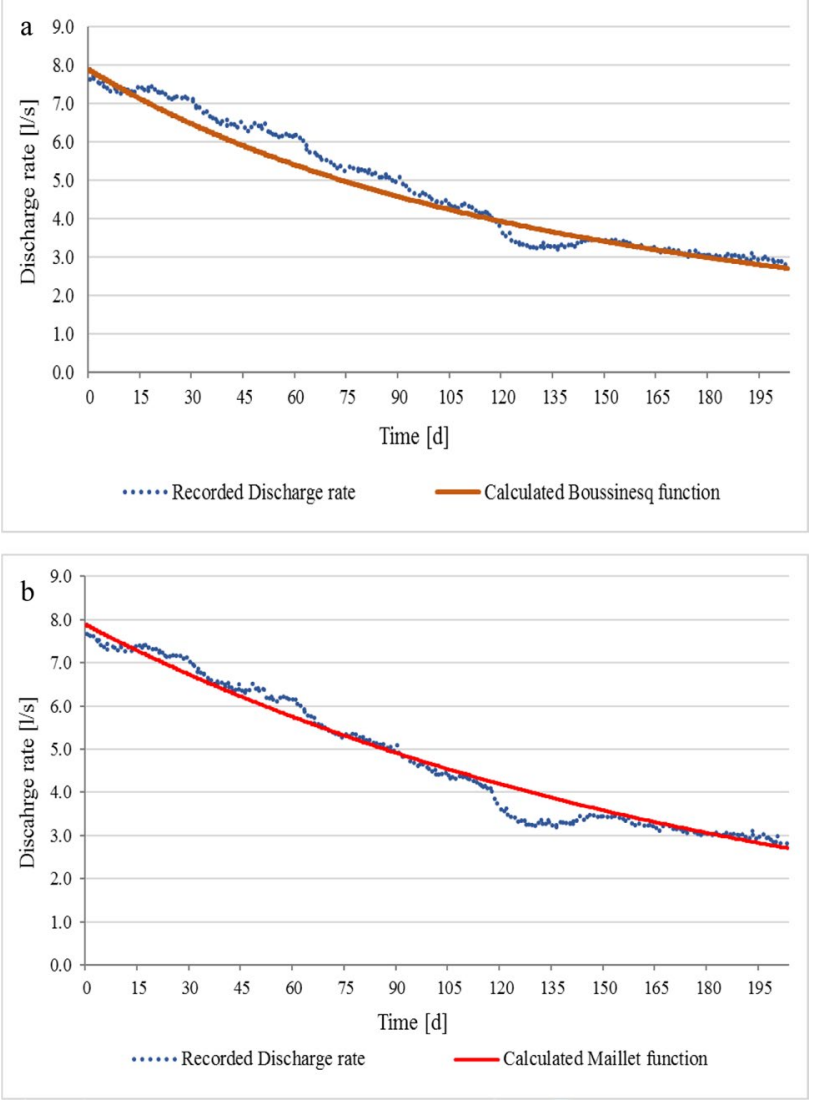

Fig. 7 Comparison between recorded discharge rate (original 4-h sampling resolution) and calculated Boussinesq (a) and Maillet (b) functions for Spring 1

Table 2 Estimated recession coefficient $(\alpha)$, groundwater volume stored in the system at the beginning of the recession process $\left(W_{0}\right)$, and groundwater volume stored at the end of the recession process $\left(W_{d}\right)$ for the two monitored springs using the Boussinesq and Maillet equations

\begin{tabular}{llcl}
\hline Case study & \multicolumn{3}{l}{ Hydrogeological parameters } \\
\hline Spring 1 & $\alpha\left[\mathrm{d}^{-1}\right]$ & $W_{0}\left[\mathrm{~m}^{3}\right]$ & $W_{d}\left[\mathrm{~m}^{3}\right]$ \\
Boussinesq (1904) & 0.0035 & 196,304 & 81,184 \\
Maillet (1905) & 0.0053 & 129,696 & 85,092 \\
Spring 2 & $\alpha\left[\mathrm{d}^{-1}\right]$ & $W_{0}\left[\mathrm{~m}^{3}\right]$ & $W_{d}\left[\mathrm{~m}^{3}\right]$ \\
Boussinesq (1904) & 0.0224 & 117,070 & 84,071 \\
Maillet (1905) & 0.0223 & 117,767 & 108,410 \\
\hline
\end{tabular}

$\mathrm{W}_{\mathrm{d}}\left(81,184 \mathrm{~m}^{3}\right.$ Boussinesq method and 85,092 $\mathrm{m}^{3}$ Maillet method).

Comparisons between the recorded discharge rate data and predicted rate data are presented in Fig. 7.

The estimated root-mean-square error (RMSE) results were equal to 0.35 and 0.27 for the Boussinesq and the Maillet equation, respectively.
In contrast, the $W_{0}$ values obtained for Spring 2 by applying the two selected different methods appear comparable $\left(117,070 \mathrm{~m}^{3}\right.$ Boussinesq method and $117,767 \mathrm{~m}^{3}$ Maillet method), while the values provided for $\mathrm{W}_{\mathrm{d}}$ turn to be divergent $\left(84,071 \mathrm{~m}^{3}\right.$ Boussinesq method and $108,410 \mathrm{~m}^{3}$ Maillet method).

As for Spring 1, comparisons between the recorded discharge rate data and the predicted rates of Spring 2 are presented in Figs. 8, to understand which methods better fit the analysed recession curve.

For Spring 2, the root-mean-square error (RMSE) results were equal to 3.52 for the Boussinesq equation and 0.84 for the Maillet one

\section{Recession analysis—simulated datasets}

Hydrogeological parameters $\left(\alpha, W_{0}, W_{d}\right)$, obtained using the original dataset (4-h sampling resolution), were subsequently compared with the ones estimated by considering simulated datasets (resampled to $1,3,7,15$, and 30 days sampling resolutions).

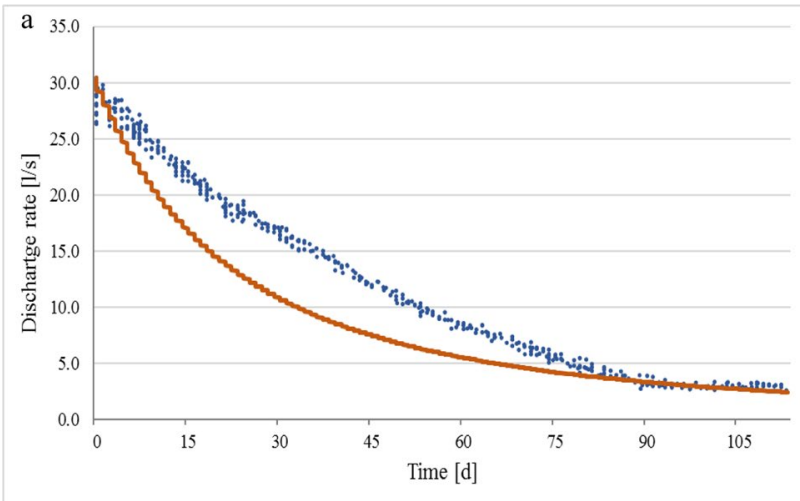

..... Recorded Discharge rate $\quad$ Calculated Boussinesq function

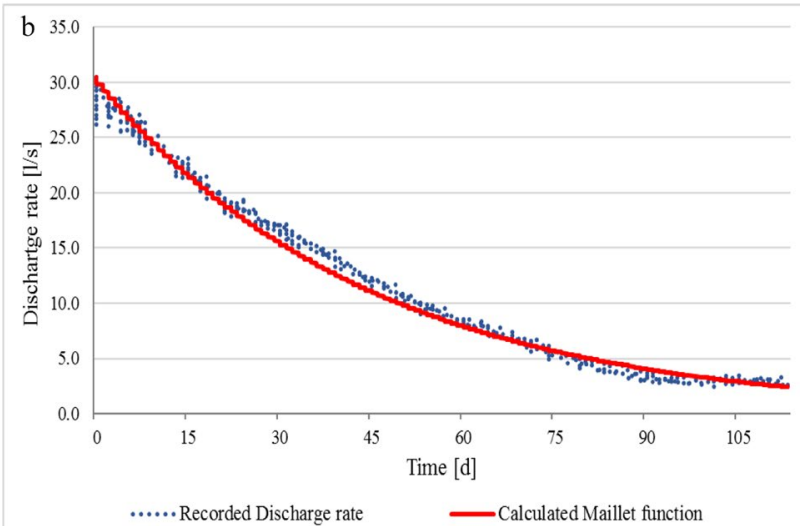

Fig. 8 Comparison between recorded discharge rate (original 4-h sampling resolution) and calculated Boussinesq (a) and Maillet (b) functions for Spring 2 


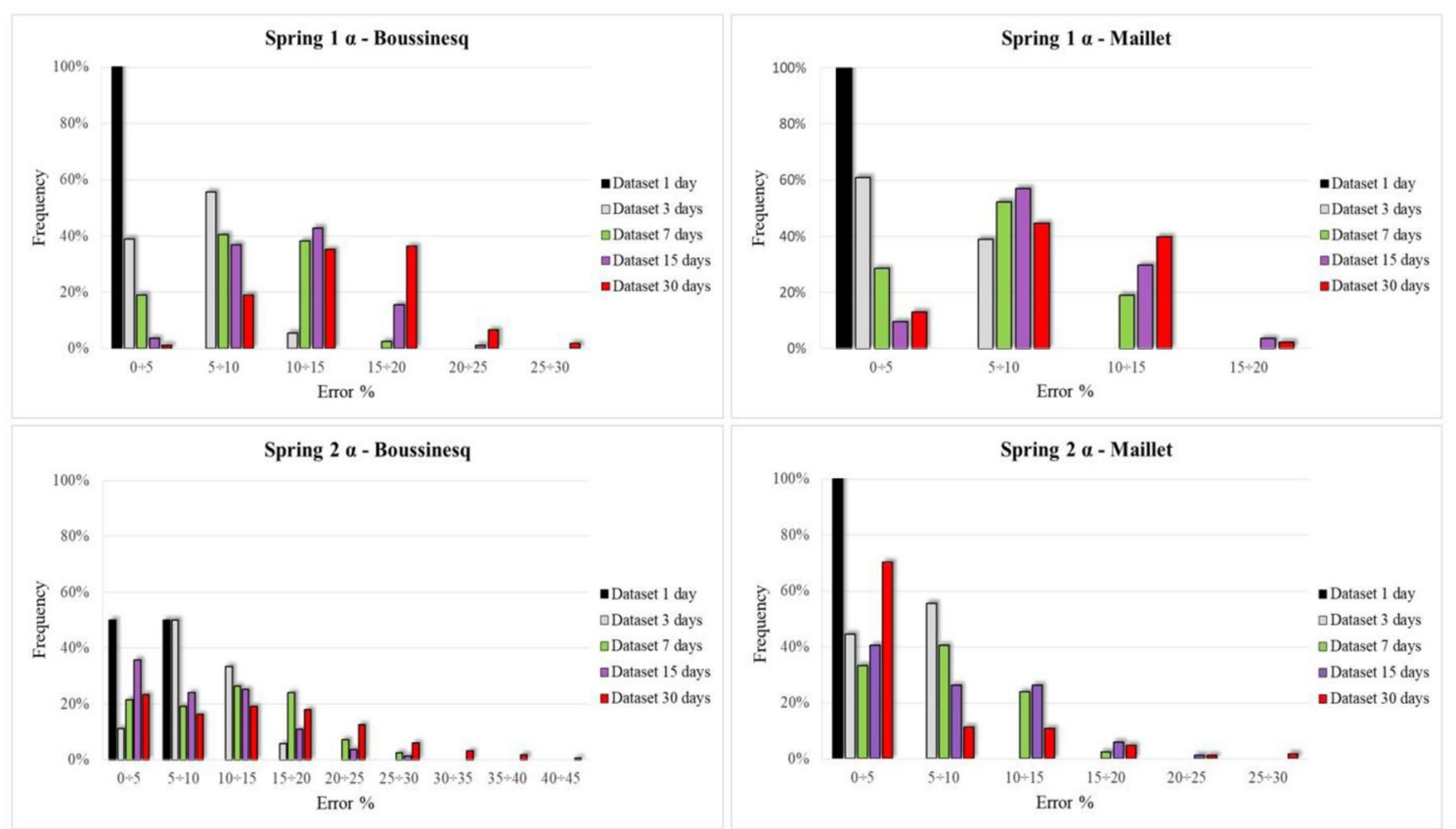

Fig.9 Distributions of estimated errors of the calculated coefficient of discharge with respect the value obtained with the original dataset (4-h sampling resolution). The errors are represented using class intervals with a range equal to 5\%
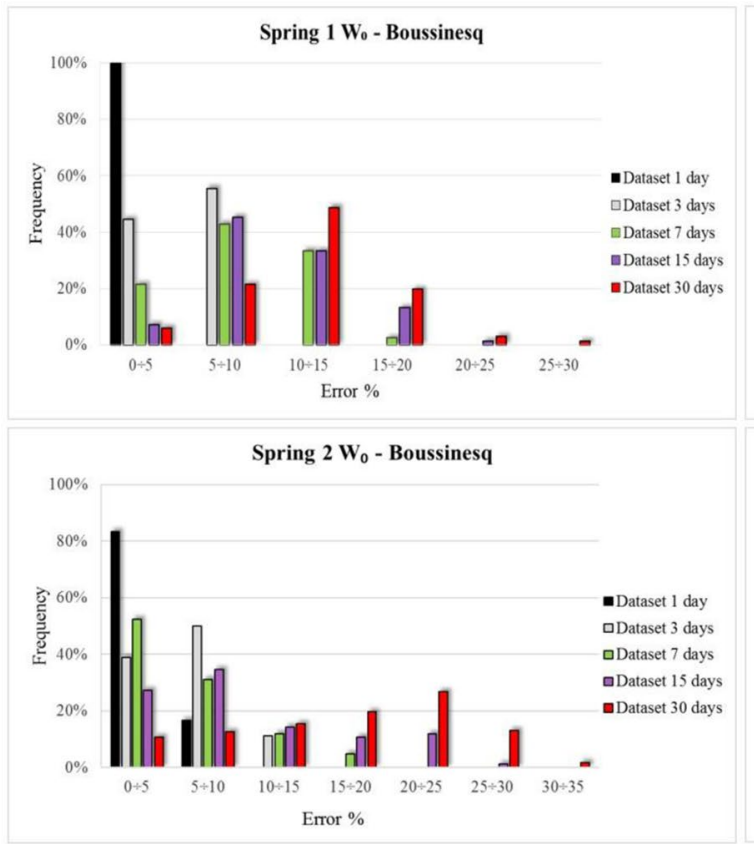
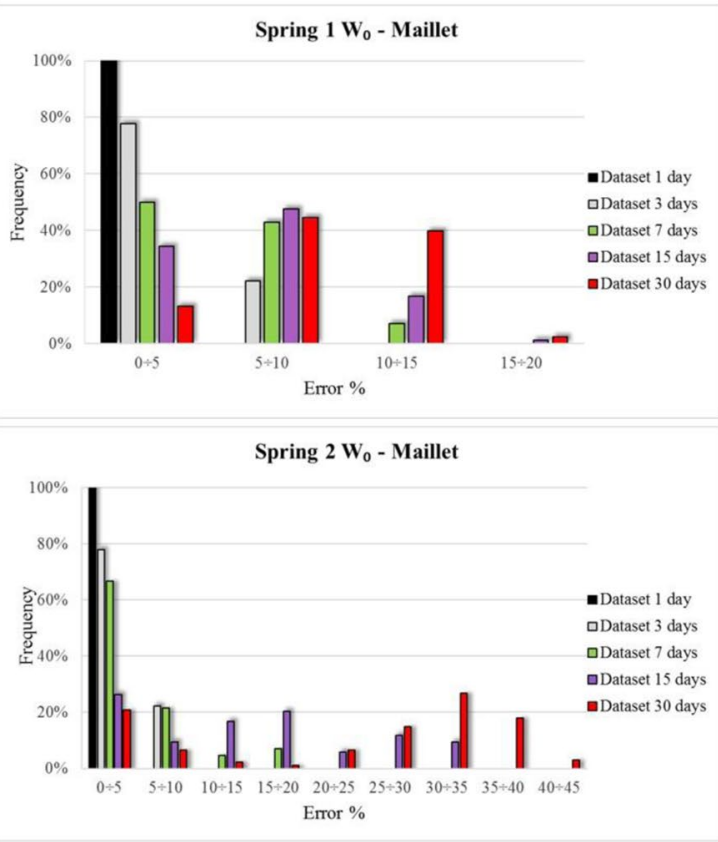

Fig.10 Distribution of estimated errors in the calculated groundwater volume stored at the beginning of recession $\left(W_{0}\right)$ with respect to the value obtained using the original dataset (4-h sampling interval). The errors are represented using class intervals with a range equal to $5 \%$

The distributions of estimated errors introduced from a less dense dataset with respect to the original dataset are reported in Figs. 9, 10 and 11. Table 3 summarizes the minimum and maximum error values obtained for each analysed case. 


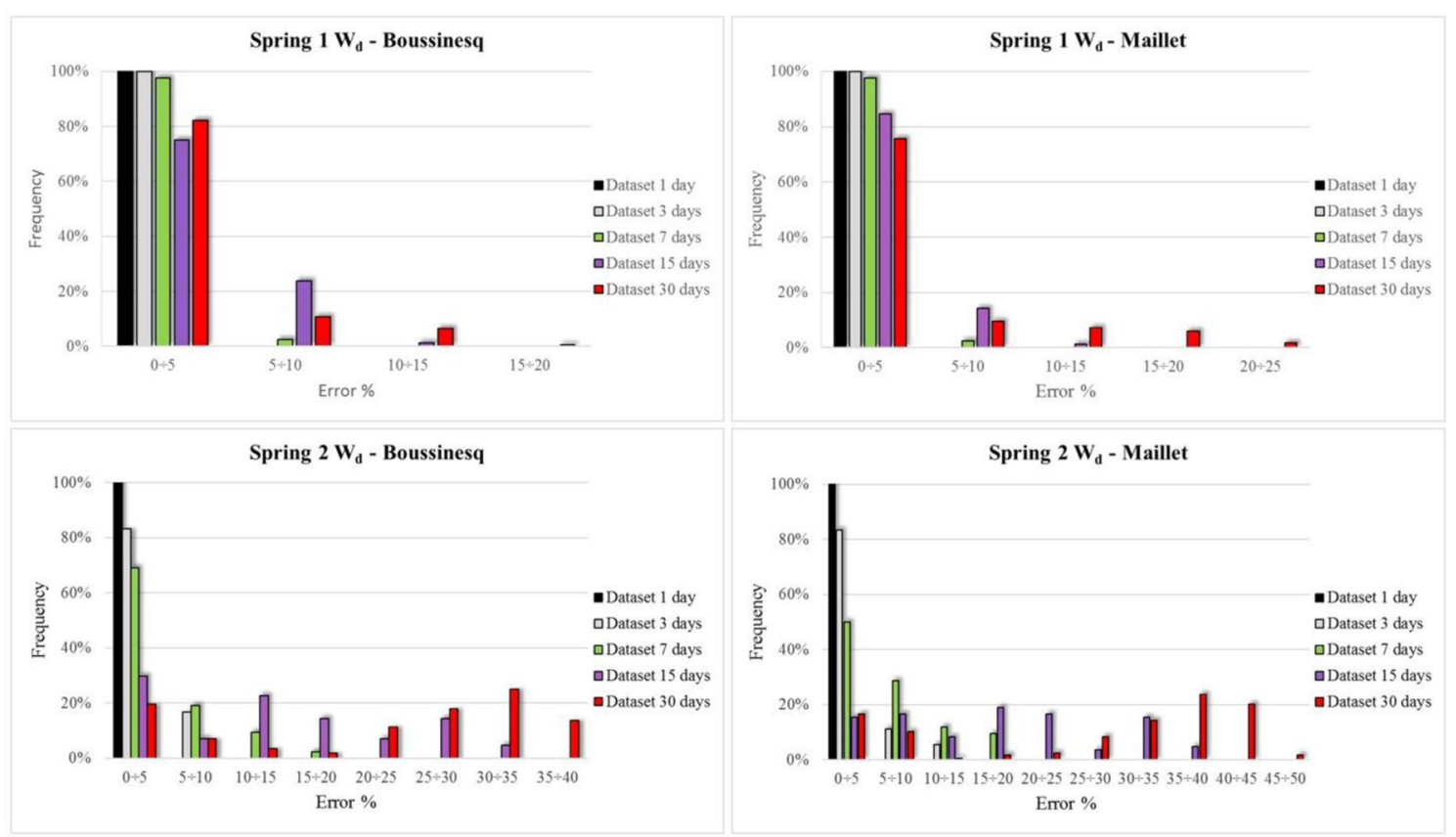

Fig. 11 Distribution of estimated errors in the calculated groundwater volume stored at the end of the recession $\left(W_{d}\right)$ with respect to the value obtained from the original dataset (4-h sampling interval). The errors are represented using class intervals with a range equal to 5\%

Table 3 Range of errors for recession coefficient $(\alpha)$, groundwater volume stored in the system at the beginning of the recession process $\left(\mathrm{W}_{0}\right)$, and groundwater volume stored at the end of the recession process $\left(\mathrm{W}_{\mathrm{d}}\right)$ estimated using monitoring data resampled to different sampling intervals for the two monitored springs

\begin{tabular}{|c|c|c|c|c|c|c|}
\hline \multirow[t]{2}{*}{ Case study } & \multicolumn{6}{|c|}{ Error range [\%] } \\
\hline & $\alpha$ & & $W_{0}$ & & $W_{d}$ & \\
\hline \multicolumn{7}{|l|}{ SPRING 1} \\
\hline Boussinesq formula & Min & Max & Min & Max & Min & Max \\
\hline 1-day sampling & 0.6 & 4.6 & 0.4 & 4.2 & 0.2 & 1.8 \\
\hline 3-day sampling & 0.6 & 10.6 & 0.4 & 9.7 & 0.2 & 4.9 \\
\hline 7-day sampling & 0.3 & 15.8 & 0.1 & 15.7 & 0.0 & 6.4 \\
\hline 15-day sampling & 2.6 & 21.5 & 2.3 & 22.3 & 0.0 & 12.1 \\
\hline 30-day sampling & 3.4 & 27.2 & 0.3 & 28.2 & 0.0 & 15.9 \\
\hline Maillet Formula & Min & Max & Min & Max & Min & Max \\
\hline 1-day sampling & 0.6 & 3.8 & 0.3 & 3.3 & 0.2 & 1.5 \\
\hline 3-day sampling & 0.6 & 8.4 & 0.3 & 7.6 & 0.2 & 4.4 \\
\hline 7-day sampling & 0.2 & 13.2 & 0.2 & 12.3 & 0.0 & 5.4 \\
\hline 15-day sampling & 0.3 & 19.0 & 0.3 & 18.6 & 0.0 & 11.0 \\
\hline 30-day sampling & 0.4 & 22.7 & 0.0 & 22.0 & 0.0 & 22.3 \\
\hline \multicolumn{7}{|l|}{ SPRING 2} \\
\hline Boussinesq Formula & Min & Max & Min & Max & Min & Max \\
\hline 1-day sampling & 0.6 & 6.3 & 0.2 & 5.2 & 0.5 & 3.2 \\
\hline 3-day sampling & 2.9 & 16.3 & 0.2 & 12.2 & 0.2 & 8.3 \\
\hline 7-day sampling & 0.2 & 28.5 & 0.2 & 19.4 & 0.0 & 16.7 \\
\hline 15-day sampling & 0.2 & 27.5 & 0.4 & 26.4 & 0.0 & 32.5 \\
\hline 30-day sampling & 0.3 & 43.9 & 0.6 & 32.5 & 0.0 & 39.7 \\
\hline Maillet Formula & Min & Max & Min & $\operatorname{Max}$ & Min & Max \\
\hline 1-day sampling & 0.2 & 3.5 & 0.1 & 3.0 & 0.8 & 3.2 \\
\hline 3-day sampling & 0.1 & 10.0 & 0.6 & 9.4 & 0.2 & 10.5 \\
\hline 7-day sampling & 0.2 & 19.5 & 0.1 & 17.5 & 0.1 & 18.8 \\
\hline 15-day sampling & 0.1 & 22.5 & 0.1 & 34.3 & 0.1 & 37.0 \\
\hline 30-day sampling & 0.1 & 29.6 & 0.1 & 41.5 & 0.1 & 46.1 \\
\hline
\end{tabular}


By considering the resampled datasets with the shortest sampling interval (1 day), the difference in recession coefficient $\alpha$ values (Fig. 9) varies between 0 and 5\% for Maillet formula; between 0 and 10\% if the Boussinesq formula is considered for the analysis of Spring 2.

The error increases to values of $10 \%$ (Maillet method) and $16.3 \%$ (Boussinesq method) by considering the 3-day sampling interval datasets.

Maximum errors of $29.6 \%$ and $43.9 \%$ were evaluated for the Maillet and Boussinesq methods, respectively, using the 30-day sampling resolution datasets.

The second analysed parameter was the groundwater volume stored at the beginning of recession, $W_{0}$ (Fig. 10).

Considering the 1-day resolution resampled datasets, the difference in $W_{0}$ values compared to the original dataset varied between 0 and $5 \%$ using the Maillet equation; between 0 and $10 \%$ for the Boussinesq equation.

The maximum error increases to $9.4 \%$ (Maillet method) and $12.2 \%$ (Boussinesq method) when considering the 3-day resolution resampled datasets. The error values continue to grow when analysing longer sampling intervals: the 7-day sampling interval datasets reach maximum errors of $17.5 \%$ (Maillet method) and 19.4\% (Boussinesq method), while the 30-day datasets reach 41.5\% (Maillet method) and 32.5\% (Boussinesq method).

Finally, for $\mathrm{W}_{\mathrm{d}}$ parameter (Fig. 11), the analysis of the 1-day sampling resolution datasets yielded an error range of $0-5 \%$ for both the Maillet and Boussinesq equations. The error increases to maximum values of $10.5 \%$ (Maillet method) and $8.3 \%$ (Boussinesq method) when considering 3-day datasets.

Analysing longer sampling intervals, the maximum error value continues to increase to $18.8 \%$ (Maillet method) and $16.7 \%$ (Boussinesq method) for the 7-day datasets and $46.1 \%$ (Maillet method) and $39.7 \%$ (Boussinesq method) for the 30-day datasets.

\section{Conclusions}

Due to climate change, urbanisation, de-forestation challenges, the development of correct management strategies for the exploitation of groundwater resources associated with mountain springs has become an increasingly important topic.

However, especially in remote alpine areas, continuous monitoring and data collection of springs' hydrogeological parameters is still often hampered by technical and logistical problems.
In many cases, the only type of data available for the derivation of geological and hydrogeological information is represented by non-continuous datasets of springs' discharge.

In this work, to identify the minimum time interval, in the recording of the spring discharge parameter, that can be considered valid for a correct estimation of aquifer groundwater reserves, recession curve analysis was carried out on two different mountain springs (Spring 1 and Spring 2).

Recession curve analysis was performed by applying Boussinesq (1904) and Maillet (1905) analytical solutions, firstly considering the available 4-h resolution Q datasets and subsequently by resampling those data to simulate longer sampling intervals of $1,3,7,15$, and 30 days.

The first outcome of this study highlighted how for these springs the Maillet exponential equation should be preferred to the Boussinesq equation, for both porous analysed springs: while the Maillet method fitted the entire recession and could provide correct estimates of the aquifer's parameters, the Boussinesq solution underestimated in both cases the dynamic volume of the aquifer.

The outcomes obtained from the analysis of the errors' distribution classes also allowed to underline that the percentage errors in the estimates of aquifer parameters $\left(W_{0}\right.$, $W_{d}$ and $\alpha$ ) increases with the time sampling interval of the flow rate $(Q)$.

The estimated percentage errors have a greater range of variation and reach the highest value in Spring 2, which is characterised by a variable discharge, than in Spring 1, associated with a sub-variable discharge behaviour.

For both analysed springs (Spring 1 and Spring 2), the ranges of error associated with the 1-day and 3-day sampling interval datasets (daily or bi-weekly datasets) were, respectively, less than 5 and $10 \%$.

In the absence of continuous datasets, these sampling resolutions can therefore be considered valid for an adequate estimation of the hydrodynamic parameters of a porous aquifer $\left(\alpha, W_{0}\right.$ and $\left.W_{d}\right)$.

In contrast, a sampling interval of 7 days recorded a range of error between 5 and 20\%. This type of sampling dataset, although it is frequently used in spring monitoring operations, turns out to be not always acceptable. Due to the maximum error close to $20 \%$ its use is suggested only for qualitative estimates of available water reserves or an analysis of different error scenarios should be performed.

Finally, due to the percentages of errors that can exceed 30\%, 15- and 30-day sampling intervals cannot be considered an appropriate dataset for estimating aquifer hydrodynamic parameters and porous spring groundwater resources. 
Authors' contributions All the authors conceived the research work aim and contributed to finding materials and analysis tools. All authors read and approved the final manuscript.

Funding Open access funding provided by Politecnico di Torino within the CRUI-CARE Agreement.

\section{Compliance with ethical standards}

Competing interests The authors declare that they have no competing interests.

Open Access This article is licensed under a Creative Commons Attribution 4.0 International License, which permits use, sharing, adaptation, distribution and reproduction in any medium or format, as long as you give appropriate credit to the original author(s) and the source, provide a link to the Creative Commons licence, and indicate if changes were made. The images or other third party material in this article are included in the article's Creative Commons licence, unless indicated otherwise in a credit line to the material. If material is not included in the article's Creative Commons licence and your intended use is not permitted by statutory regulation or exceeds the permitted use, you will need to obtain permission directly from the copyright holder. To view a copy of this licence, visit http://creativecommons.org/licenses/by/4.0/.

\section{References}

Amit H, Lyakhovsky V, Katz A, Starinsky A, Burg A (2002) Interpretation of spring recession curves. Ground Water 40(5):543-551

Banzato C, Governa M, Petricig M, Vigna B (2015) The importance of monitoring for the determination of aquifer vulnerability and spring protection areas. In: Lollino G, Manconi A, Guzzetti F, Culshaw M, Bobrowsky P, Luino F (eds) Engineering geology for society and territory, vol 5. Springer, Cham. https://doi.org/ 10.1007/978-3-319-09048-1_264

Banzato C, Butera I, Revelli R, Vigna B (2017) Reliability of the VESPA index in identifying spring vulnerability level. J Hydrol Eng 22(6):04017008

Boussinesq J (1877) Essai sur la théorie des eaux courantes do mouvement non-permanent des eaux souterraines. Acad Sci Inst Fr 23:252-260

Boussinesq J (1904) Recherches théoriques sur l'écoulement des nappes d'eau infiltrées dans le sol et sur le débit des sources. J Math Pure Appl 10:5-78

Cambi C, Dragoni W (2000) Groundwater yield, climatic changes and recharge variability: considerations out of the modelling of a spring in the Umbria-Marche Apennines. Hydrogéologie 4:11-25

Cervi F, Marcaccio M, Petronici F, Borgatti L (2014) Hydrogeological characterization of peculiar Apenninic springs. Evolving water resources systems: understanding, predicting and managing water-society interactions. Proceedings of ICWRS2014, Bologna, Italy, June 2014, IAHS Publ. 364

Civita MV (2008) An improved method for delineating source protection zones for karst springs based on analysis of recession curve data. Hydrogeol J 16(5):855-869

De Luca DA, Cerino Abdin E, Forno MG, Gattiglio M, Gianotti F, Lasagna M (2019) The montellina spring as an example of water circulation in an alpine DSGSD context (NW Italy). Water. https:// doi.org/10.3390/w11040700
Desmarais K, Rojstaczer S (2001) Inferring source water from measurements of carbonate spring response to storms. J Hydrol 260:118-134

Dewandel B, Perrin J, Ahmed S, Aulong S, Hrkal Z, Lachassagne P, Samad M, Massuel S (2010) Development of a tool for managing groundwater resources in semi-arid hard rock regions: application to a rural watershed in South India. Hydrol Process 24(19):2784-2797

Fiorillo F, Doglioni A (2010) The relation between karst spring discharge and rainfall by cross-correlation analysis (Campania, southern Italy). Hydrogeol J 18(8):1881-1895

Fiorillo F, Esposito L, Guadagno FM (2007) Analysis and forecast of water resources in an ultra-centenarian spring discharge series from Serino (southern Italy). J Hydrol 336:125-138

Fiorillo F, Revellino P, Ventafridda G (2012) Karst aquifer draining during dry periods. J Cave Stud 74:148-156

Galleani L, Vigna B, Banzato C, Lo Russo S (2011) Validation of a vulnerability estimator for spring protection areas: the VESPA index. J Hydrol 396:233-245

Gattinoni P, Francani V (2010) Depletion risk assessment of the Nossana Spring (Bergamo, Italy) based on the stochastic modeling of recharge. Hydrogeol J 18:325-337

Giacopetti M, Aringoli D, Materazzi M, Pambianchi G, Posavec K (2016) Groundwater recharge estimation using spring hydrographs: the case of the Tennacola carbonate aquifer (central Apennine, Italy). Rend Online Soc Geol It 41:61-64

Istat (2018) Giornata mondiale dell'acqua, le statistiche dell' Istat. https://www.istat.it/it/archivio/228753. Accessed 15 Sept 2019

Jakada H, Chen Z, Luo M, Zhou H, Wang Z, Habib M (2019) Watershed characterization and hydrograph recession analysis: a comparative look at a karst vs. non-karst watershed and implications for groundwater resources in Gaolan River Basin Southern China. Water 11:743

Kresic N (2007) Hydrogeology and Groundwater Modeling, 2nd edn. CRC Press/Taylor and Francis, Boca Raton

Kresic N, Bonacci O (2010) Spring discharge hydrograph. Groundwater hydrology of springs, 1st edn. Butterworth-Heinemann, Elsevier Inc, pp 129-163

Lo Russo S, Amanzio G, Ghione R, De Maio M (2014) Recession hydrographs and time series analysis of springs monitoring data: application on porous and shallow aquifers in mountain areas (Aosta Valley). Environ Earth Sci 73:7415-7434

Lo Russo S, Taddia G, Cerino Abdin E (2015) Tunneling and groundwater interaction: the role of the hydrogeological monitoring. Geoingegneria Ambientale e Mineraria 146(3):37-44

Maillet E (1905) Essais d'hydraulique souterraine et fluviale, vol 1. Herman et Cie, Paris, p 218

Meinzer OE (1927) Outline of ground water hydrology. U.S Geological Survey, Washington

Nathan RJ, McMahon TA (1990) Evaluation of automated techniques for base flow and recession analysis. Water Resour Res 26:1465-1473

Ostermann M, Koltai G, Spötl C, Cheng H (2016) Deep-seated gravitational slope deformations in the Vinschgau (northern Italy) and their association with springs and speleothems. In: Proceedings of the EGU general assembly conference abstracts, Vienna, Austria, 17-22 April 2016

Polino R, Borghi A, Carraro F, Dela Pierre F, Fioraso G, Giardino M (2002) Note illustrative della Carta Geologica D'Italia alla scala 1:50.000-Foglio 132-152-153 "Bardonecchia". APAT Servizio Geologico d'Italia

Roques C, Rupp DE, Selker JS (2017) Improved streamflow recession parameter estimation with attention to calculation of - $d Q / d t$. Adv Water Resour 108:29-43

Rupp DE, Selker JS (2006) Information, artifacs and noise in dQ/dt-Q recession analysis. Adv Water Resour 29(2):154-160 
Shevenell L (1996) Analysis of well hydrographs in a karst aquifer: estimates of specific yields and continuum transmissivities. J Hydrol 174:331-355

Sugiyama H (1996) Analysis and extraction of low flow recession characteristics. Water Resour Bull 32:491-497

Tallaksen LM (1995) A review of baseflow recession analysis. J Hydrol 165:349-370

Tobin BW, Schwartz BF (2016) Using periodic hydrologic and geochemical sampling with limited continuous monitoring to characterize remote karst aquifers in the Kaweah River Basin, California. USA Hydrol Process 30:3361-3372

Unesco (2019) United Nations World Water Development Report. https://www.unwater.org/publications/world-water-developmentreport-2019/. Accessed 20 Jan 2021
Vashisht AK, Bam B (2013) Formulating the spring discharge-function for the recession period by analyzing its recession curve: a case study of the Ranichauri spring (India). J Earth Syst Sci 122(5):1313-1323

Publisher's Note Springer Nature remains neutral with regard to jurisdictional claims in published maps and institutional affiliations. 